\title{
Spatial Distribution of Picophytoplankton in Southeastern Coast of Peninsular Malaysia Using Flow Cytometry
}

\author{
Roswati Md Amin ${ }^{1}$, Md Suffian Idris ${ }^{1 *}$, Nurul Asmera Mudiman ${ }^{1}$, Noor Hazwani \\ Mohd Azmi ${ }^{2}$ and Hing Lee Siang ${ }^{1}$
}

${ }^{1}$ Faculty of Science and Marine Environment, Universiti Malaysia Terengganu, 21030 Kuala Nerus, Terengganu, Malaysia

${ }^{2}$ Institute of Oceanography and Environment, Universiti Malaysia Terengganu, 21030 Kuala Nerus, Terengganu, Malaysia

\begin{abstract}
The distribution of picocyanobacteria from two genera, Synechococcus and Prochlorococcus, and picoeukaryotes in surface water $(0.5 \mathrm{~m})$ was investigated by flow cytometry in the southeastern coast of Peninsular Malaysia during the Southwest monsoon in August 2014. During the cruise, Synechococcus cells were predominant throughout the study area, contributing as much as $50 \%$ to the total picophytoplankton population, whereas picoeukaryotes and Prochlorococcus constituted only $31 \%$ and $19 \%$ of the population, respectively. Spatially, Synechococcus and picoeukaryotes were more dominant in

ARTICLE INFO

Article history:

Received: 18 December 2020

Accepted: 24 February 2021

Published: 19 July 2021

DOI: https://doi.org/10.47836/pjst.29.3.18

E-mail addresses:

roswati_ma@umt.edu.my (Roswati Md Amin)

suffian@umt.edu.my (Md Suffian Idris)

nurulasmera.mudiman@gmail.com (Nurul Asmera Mudiman)

noorhazwanimohdazmi@gmail.com (Noor Hazwani Mohd Azmi)

1shing@umt.edu.my (Hing Lee Siang)

*Corresponding author

coastal waters, while Prochlorococcus appeared to be more highly abundant in offshore waters. Furthermore, the percentage contribution of each population to total picophytoplankton also exhibited different spatial distribution patterns along a coastal-offshore gradient. The percentage contribution of Synechococcus was spatially constant throughout the study area, while the fraction contributed by picoeukaryotes showed a reduced contribution from coastal to offshore waters. In contrast, Prochlorococcus exhibited an increased proportion to total picophytoplankton across
\end{abstract}


a coastal-offshore gradient, suggesting the increasing importance of this population in offshore waters of the study area. As revealed by Canonical Correlation Analysis, the abundance of Synechococcus and picoeukaryotes increased significantly with reducing dissolved oxygen levels and $\mathrm{pH}$, and with increasing total chlorophyll. In contrast, temperature was the only factor influencing the abundance of Prochlorococcus significantly increased with decreasing water temperature in the study area. Overall, results of the present study provide valuable information on the role of regional environmental factors in the distribution and dominance of picophytoplankton communities that are not only critical for the ocean productivity but also the impact on the carbon cycle in the study area.

Keywords: Picoeukaryotes, picophytoplankton, Prochlorococcus, South China Sea, Synechococcus

\section{INTRODUCTION}

Picophytoplankton, generally known as phytoplankton with a diameter of less than 2 or $3 \mu \mathrm{m}$, is the smallest phytoplankton class composed of both prokaryotes and eukaryotes. The eukaryotes $(0.8-3 \mu \mathrm{m})$ are a taxonomically complex group comprising members of four algal phyla: The Chlorophyta, Haptophyta, Cryptophyta and Heterokontophyta (Vaulot et al., 2008). The prokaryotes are a member of the Cyanobacteria, class Cyanophyceae and order Synechococcales and are subdivided into the genera Prochlorococcus $(\sim 0.6 \mu \mathrm{m})$ and Synechococcus $(\sim 1 \mu \mathrm{m})$. Picophytoplankton has been described as the smallest known autotrophic species; it is of great significance and present in all oceanic provinces. They contribute up to $90 \%$ of chlorophyll present in particulate matter < $2.0 \mu \mathrm{m}$ (Guiry \& Guiry, 2016; Miyashita, 2015; Scanlan, 2012).

Synechococcus distribution is ubiquitous from the open ocean to the coastal area in most of the world's oceans (Gin et al., 2003; Li, 1998) while Prochlorococcus tends to be abundant in oligotrophic waters (Campbell et al., 1994; Partensky et al., 1999a; Partensky et al., 1999b). Although the abundance of Prochlorococcus generally exceeds Synechococcus in areas where they co-exist, there are several conditions that allow Synechococcus to thrive. These include regions that are permanently or seasonally enriched with nutrients (Partensky et al., 1999a). Meanwhile, Prochlorococcus thrives through the euphotic zone of tropical and subtropical oligotrophic oceans (Chisholm et al., 1988). This is due to traits that make them well-adapted to the oligotrophic environment (Biller et al., 2015) such as a small size that facilitates efficient nutrient and enhanced light absorption (Moore et al., 1995). As a result, these traits enable Prochlorococcus to thrive at low light intensities (Moore et al., 1995) and in deeper waters (Zwirglmaier et al., 2008). On the other hand, autotrophic picoeukaryotes show enhanced abundance in coastal eutrophic waters, where they can surpass picocyanobacteria in terms of biomass (Pan et al., 2007). 
Prokaryotic growth and distribution studies in most oceanic regions indicate that prokaryotes have a significant effect on carbon cycling processes, not only by assimilating photosynthetically derived organic matter but also by serving as a major food resource for heterotrophic flagellates, ciliates (Gasol et al., 1997; Lønborg \& Søndergaard, 2009). Several biotic and abiotic factors can interact to affect the picoplankton assemblage composition and cell abundances. Abiotic factors, known to drive bottom-up control include temperature, salinity, as well as availability of light and nutrient. Biotic factors attributed to top-down control, include predation by nano- and microzooplankton, as well as virioplankton lysis (Evans \& Brussaard, 2012).

Despite the growing knowledge of picophytoplankton, Prochlorococcus and Synechococcus and their co-occurrence in ocean and coastal waters, little is known about their abundance and distribution in Malaysian waters. The distribution of picophytoplankton in tropical water has been the subject of past research in the Philippines (Agawin et al., 2003; Zhao et al., 2010), Vietnam, western South China Sea (Chen et al., 2009) and Nansha Island, South China Sea (Yang \& Jiao, 2004). However, to date only data on the abundance of Prochlorococcus and Synechococcus in the Johor Strait, Malaysia is published (Gin et al., 2000; Gin et al., 2003). Latest reports on general phototrophic picoplankton studies are available, i.e., on the diel variation and distribution in mangrove areas of Melaka (Lee et al., 2006) and Klang estuary (Lee et al., 2013). Therefore, this is the first study on the distribution of Synechococcus, Prochlorococcus and picoeukaryotes, documented by using a flow cytometer, in the southeastern coast of Peninsular Malaysia. This aims to increase our understanding on the structures of phytoplankton assemblages in our areas. Direct analysis using flow cytometry provides information on the abundance and pigment content of the major photosynthetic picophytoplankton groups (Marie et al., 2005).

\section{MATERIALS AND METHODS}

\section{Field Sampling and Study Area}

Field sampling was conducted in the southeastern coast of Peninsular Malaysia from 18th to 24th August 2014 on board UMT's RV Discovery, covering an area from Pahang to Johor waters $\left(1^{\circ} 45^{\prime}-4^{\circ} 00^{\prime} \mathrm{N}\right.$ and $\left.103^{\circ} 30^{\prime}-104^{\circ} 44^{\prime} \mathrm{E}\right)$ (Figure 1). Samplings were performed at 18 stations along 6 coastal-offshore transects from depths between $10 \mathrm{~m}$ and $70 \mathrm{~m}$. Each transect (denoted by numbers 1 to 6 ) consists of three to four measurement stations located between coastal (stations with letter "a") and offshore waters (stations with letter "d").

At each station, hydrographical parameters of the surface water, such as temperature, salinity, $\mathrm{pH}$, and dissolved oxygen (DO) were measured from vertical profile with a CTD (SBE 19 plus, Sea-Bird Electronic Inc., USA). This instrument was calibrated by the manufacturer before the cruise. A known volume of water samples (1 - 5 L depending on particle load) for chlorophyll (Chl) and picophytoplankton abundance were collected using a 


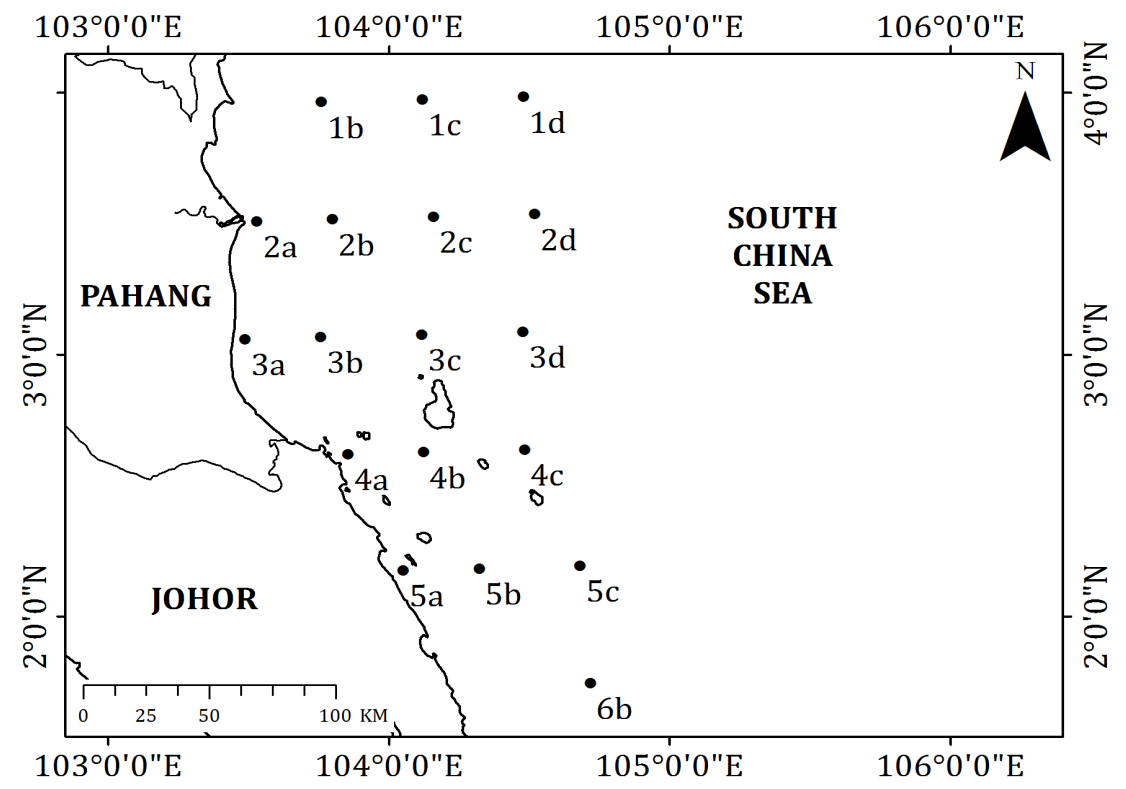

Figure 1. Location of sampling stations in southeastern coast of Peninsular Malaysia

water pump from approximately $0.5 \mathrm{~m}$ depth and transferred into a $10 \mathrm{~L}$ dark bottle. Water samples were filtered onboard immediately after collection under low vacuum pressure (less than $0.5 \mathrm{~atm})$. For the total chlorophyll (TChl) concentration, only one replication of water sample was collected at each station and samples were directly concentrated onto $0.7-\mu \mathrm{m}$ pore-size Whatman glass-fibre filters $(\mathrm{GF} / \mathrm{F})$. For flow cytometry counts, triplicate $2 \mathrm{~mL}$ of water samples were collected with GF/D $(2.7 \mu \mathrm{m})$ and fixed immediately with $10 \%$ cold glutaraldehyde (final concentration 1\%). All samples were stored in the dark at $-20^{\circ} \mathrm{C}$ until analysis in the laboratory (Vaulot et al., 1989).

\section{Laboratory Analysis of Chlorophyll Concentration and Flow Cytometry}

Chlorophyll concentration was determined spectrophotometrically using a Shimadzu double beam Spectrophotometer (Agilent Technologies). The particulate matter retained on the filters was extracted in $90 \%$ acetone before being refrigerated at $4^{\circ} \mathrm{C}$ for 8 to 24 hours. The chlorophyll absorbances were determined at 750 (background correction), 664, 647 and $630 \mathrm{~nm}$, with $1 \mathrm{~cm}$ quartz cuvette. To ensure accurate and consistent results, the spectrophotometer was programmed to take at least five repeated measurements of absorbance and averaged to a single value if the coefficient of variation (cv) was below $50 \%$. Absorbances of each wavelength were referenced against a buffered $90 \%$ acetone blank which was inserted after every 4-5 samples. The trichromatic equations of Jeffrey 
and Humphrey (1975) were used to convert absorbances to concentrations of chlorophyll. Since this method may include contributions from other pigments (especially phaeophytin), the symbol TChl rather than Chl-a will be used hereafter to represent the chlorophyll concentration.

Cell abundance of Synechococcus, Prochlorococcus and picoeukaryotes were determined according to Liu et al. (2014) using a BD Accuriт ${ }^{\mathrm{TM}}$ C6 flow cytometer (Ann Arbor, MI, USA) excited with blue $(488 \mathrm{~nm})$ and red $(640 \mathrm{~nm})$ emissions of argon lasers, and four fluorescent emission optical filters (FL1-FL4). Prior to analysis, samples were thawed at room temperature and maintained on ice in a dark container until processing. Approximately $100 \mu \mathrm{L}$ of sample was run under medium flow rate $\left(35 \mu \mathrm{L} \mathrm{min}^{-1}\right)$, with a threshold set at 800 for chlorophyll (FL3) axis. Forward scatter (FSC; indicative of the cell size and shape), side scatter (SSC; indicative of cell granularity), chlorophyll (Chl; >640 nm, FL3), phycocyanin (PC; $675 \pm 12.5 \mathrm{~nm}, \mathrm{FL} 4$ ), and phycoerythrin (PE; $585 \pm 20 \mathrm{~nm}, \mathrm{FL} 2$ ) were recorded for each cell. Picophytoplankton groups were discriminated and specified according to their specific fluorescence properties, based on FL2 (orange fluorescence) vs. FL3 (red fluorescence) and side scatter vs. FL3 signatures (Liu et al., 2014).

\section{Data Analysis}

Flow cytometric data were analyzed using the Flowjo software (Treestar, Inc., www. flowjo.com). The Pearson correlation and Canonical Correlation Analysis (CCA) were used to determine the relationship between picophytoplankton groups (Synechococcus, Prochlorococcus and picoeukaryotes) and environmental factors (TChl, temperature, salinity, $\mathrm{pH}$, and DO). Picophytoplankton abundances were log-transformed prior to CCA analysis. All statistical analyses were performed using R software version 3.6.0 (CCA and CCP packages; https://cran.r-project.org/web/packages/).

\section{RESULTS}

\section{Hydrographical Parameters}

The data range of hydrographic and biogeochemical parameters (surface temperature, salinity, $\mathrm{pH}, \mathrm{DO}$, and TChl) during the study period are summarized in Table 1 while Figure 2 shows their spatial distributions. In general, all the hydrographic parameters (temperature, salinity, $\mathrm{pH}$, and DO) varied little from coastal to offshore waters (coefficient of variation, $C V<1.5 \%$ ) (Table 1). Sea surface temperature varied from 28.47 to $29.65^{\circ} \mathrm{C}$ with the mean of $29.01 \pm 0.31{ }^{\circ} \mathrm{C}$ and no discernible spatial pattern was observed in the horizontal temperature gradient from coastal to offshore waters (Figure 2A). The non-uniform spatial pattern of surface temperature could probably be due to diurnal warming as field observations at each station were made during different daylight hours. As can be seen in Figure 2A, the highest water temperature $\left(29.4^{\circ} \mathrm{C}\right)$ was found 
at the coastal stations (stations $2 \mathrm{a}$ and $3 \mathrm{a}$ ) and in the middle of the study area (station $4 \mathrm{~b}$ ) while the lowest temperature $\left(\sim 28.5^{\circ} \mathrm{C}\right)$ was mainly observed in offshore stations. Isolated, small patches of colder waters were also observed at stations $1 \mathrm{~b}$ and $4 \mathrm{a}$. In general, the water column was almost isothermal (well-mixed) in coastal waters but showed strong thermal stratification, with mixed layer depth of more than $40 \mathrm{~m}$ in offshore waters (Figure 3A). The surface salinity for the entire dataset varied slightly, ranging from 32.34 to 33.11 psu, with the mean value of $32.70 \pm 0.22 \mathrm{psu}$. Spatially, high salinity values ( $>33 \mathrm{psu})$ were observed in coastal waters distributed along the northern regions of the study area. Water masses of low salinity ( $\sim 32.5 \mathrm{psu})$ flanked on either side by high-salinity waters were also observed in the central part of the study area (Figure 2B). High saline waters were mainly found at stations $2 \mathrm{~b}$ and $3 \mathrm{~b}$, while low saline waters were found at station $5 \mathrm{~b}$. Similar to the trend observed in temperature, the vertical salinity at near-shore stations was almost homogeneous (between 32.3 and $33.1 \mathrm{psu}$ ) through the whole water column but was well-stratified at offshore stations (Figure 3B). The effects of river discharge and tidal mixing are suggested to be the dominant factors influencing salinity distribution in the study area. Surface $\mathrm{pH}$ varied over a small range (8.08 - 8.22), averaging about 8.15 \pm 0.04 (Table 1 ). The distribution of this parameter showed a clear spatial variability, with low $\mathrm{pH}$ water masses $(\sim \mathrm{pH} 8.1)$ mainly found along the coast and more alkaline waters $(\sim \mathrm{pH} 8.2)$ at offshore stations (Figure $2 \mathrm{C})$. Differently from $\mathrm{pH}, \mathrm{DO}$ displayed patches of oxygen depletions $\left(\sim 5.7 \mathrm{mg} \mathrm{L}^{-1}\right)$ at coastal stations (stations $4 \mathrm{a}$ and $5 \mathrm{a}$ ) and maximum values $\left(\sim 6.0 \mathrm{mg} \mathrm{L}^{-1}\right)$ in the middle parts of the study area (stations $4 \mathrm{~b}$ and $5 b$ ) and offshore stations (station 1d) (Figure 2D). Across the study area, measured DO values varied from a minimum of 5.74 to a maximum of $6.07 \mathrm{mg} \mathrm{L}^{-1}(5.95 \pm 0.09)$. In general, total chlorophyll (TChl) concentrations showed a clear difference in values $(C V$ $=64.1 \%$, with relatively clear waters and low concentrations $\left(\sim 0.2 \mathrm{mg} \mathrm{m}^{-3}\right)$ at offshore stations and high values $\left(\sim 0.8 \mathrm{mg} \mathrm{m}^{-3}\right)$ at coastal stations with the highest concentration of TChl ( 1.0 $\left.\mathrm{mg} \mathrm{L}^{-1}\right)$ was mainly found at station 3a (Figure 2E). The concentration of TChl for the entire data set varied widely from coastal to offshore stations, ranging from 0.17 to $0.94 \mathrm{mg} \mathrm{m}^{-3}$ (mean $0.37 \pm 0.24$ ) (Table 1 ).

The results of correlation analysis using the Pearson correlation coefficient between environmental variables are illustrated in Table 2. Analysis of data showed that $\mathrm{pH}$ had a strong positive correlation with DO concentration $(r=0.80 ; \mathrm{p}<0.05)$. Correlation analysis also revealed that $\mathrm{TChl}$ concentration had a strong negative correlation with $\mathrm{pH}(\mathrm{r}=-0.77$; $\mathrm{p}<0.05)$ and DO $(\mathrm{r}=-0.71 ; \mathrm{p}<0.05)$ but only a weak positive correlation with temperature $(r=0.47 ; p<0.05)$. No significant relation $(\mathrm{p}>0.05)$ was observed between TChl and salinity. On the hand, a significant weak correlation $(r=0.40 ; p<0.05)$ was also found between temperature and salinity. 


\section{Table 1}

Average (mean \pm standard deviation), range, and coefficient of variation ( $C V, \%)$ values of surface temperature, salinity, $\mathrm{pH}$, dissolved oxygen (DO) and total chlorophyll (TChl) concentration); of all stations during August 2014 in the southeastern coast of Peninsular Malaysia

\begin{tabular}{cccccc}
\hline Parameter & Temp $\left({ }^{\circ} \mathrm{C}\right)$ & Salinity $(\mathrm{psu})$ & $\mathrm{pH}$ & $\mathrm{DO}\left(\mathrm{mg} \mathrm{L}^{-1}\right)$ & $\begin{array}{c}\mathrm{TChl} \\
\left(\mathrm{mg} \mathrm{m}^{-3}\right)\end{array}$ \\
\hline Average & $29.01 \pm 0.31$ & $32.70 \pm 0.22$ & $8.15 \pm 0.04$ & $5.95 \pm 0.09$ & $0.37 \pm 0.24$ \\
Range & $28.47-29.65$ & $32.34-33.11$ & $8.08-8.22$ & $5.74-6.07$ & $0.17-0.94$ \\
CV & $1.10 \%$ & $0.70 \%$ & $0.50 \%$ & $1.50 \%$ & $64.10 \%$ \\
\hline
\end{tabular}
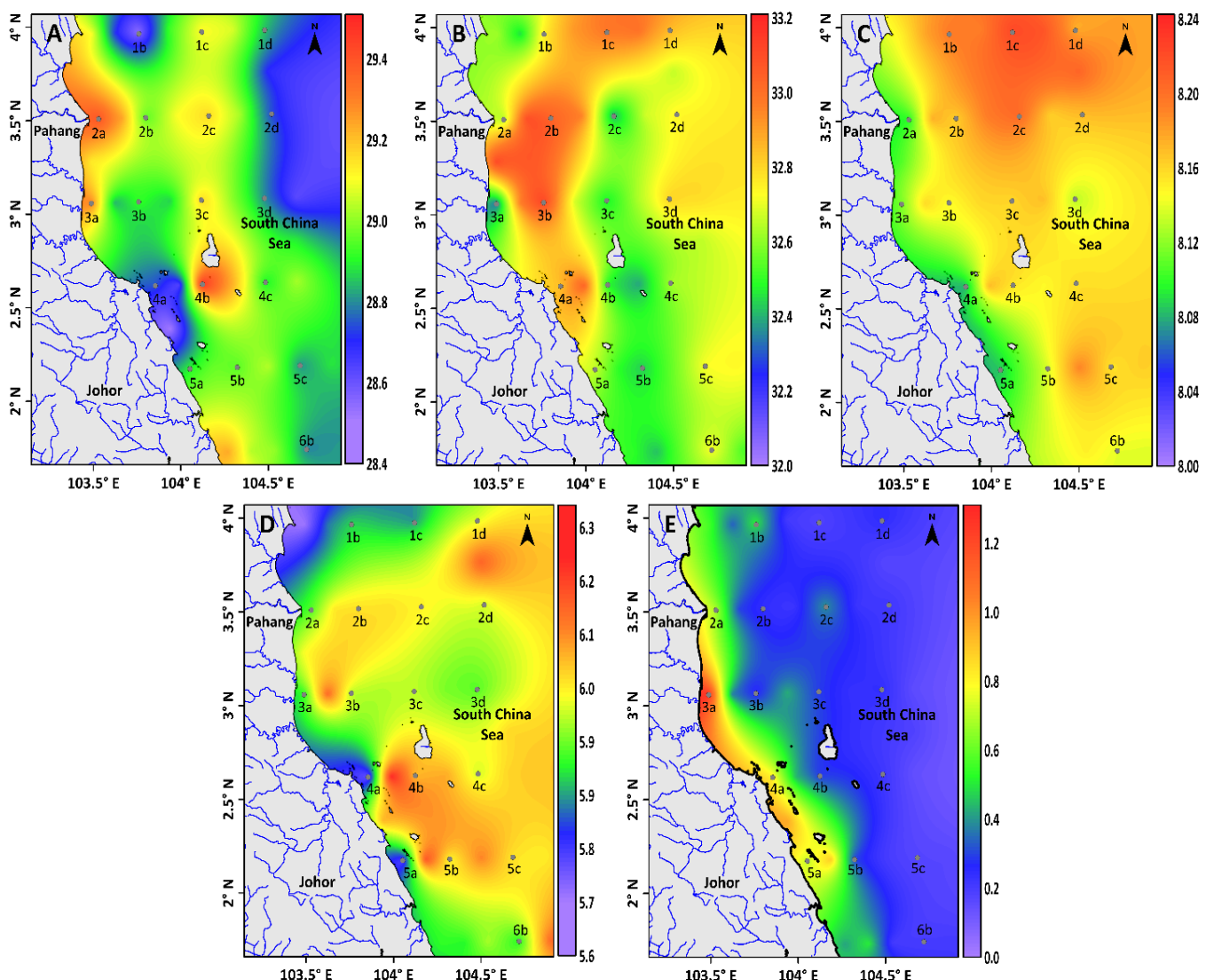

Figure 2. Spatial distributions of sea surface (A) temperature $\left({ }^{\circ} \mathrm{C}\right)$, (B) salinity (psu), (C) $\mathrm{pH}$, (D) dissolved oxygen ( $\left.\mathrm{mg} \mathrm{L}^{-1}\right)$, and $(\mathrm{E}) \mathrm{TChl}\left(\mathrm{mg} \mathrm{m}^{-3}\right)$ in the southeastern coast of Peninsular Malaysia 

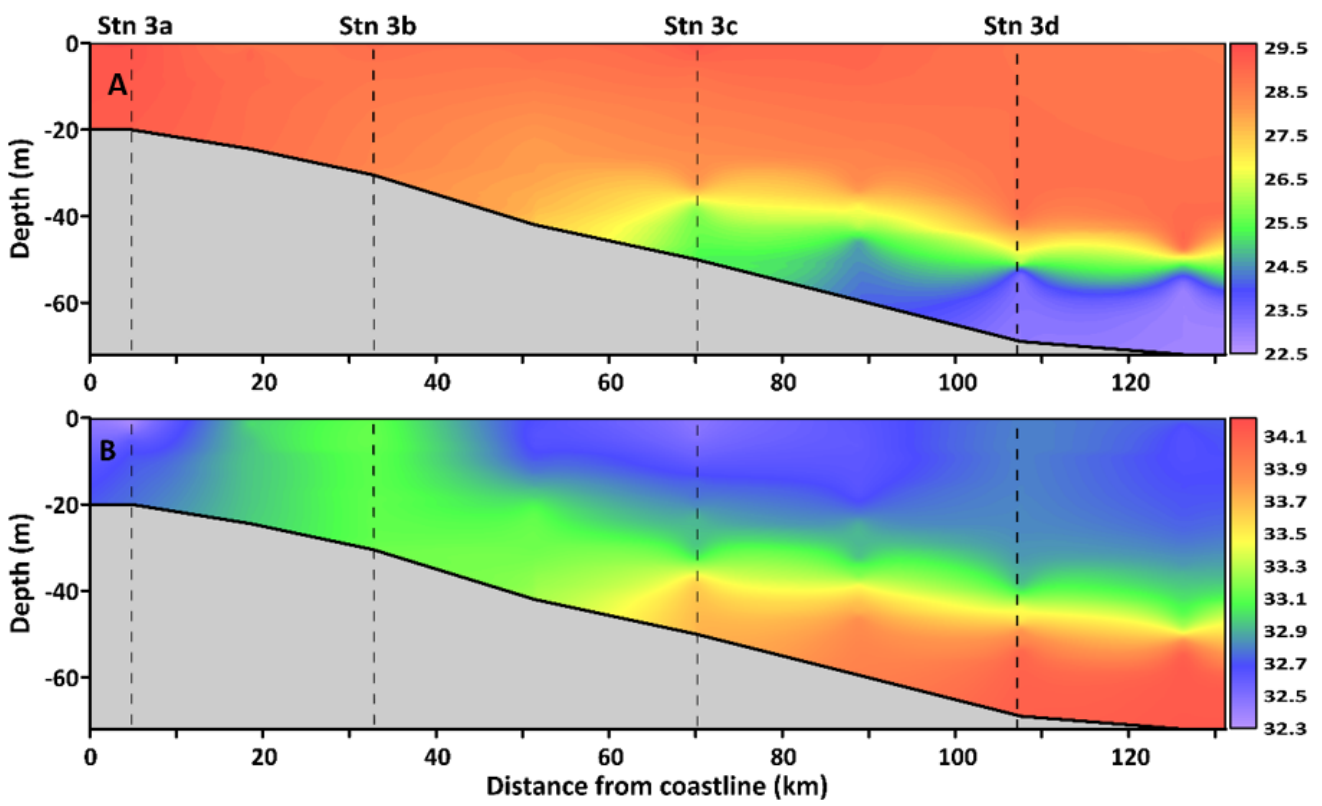

Figure 3. Cross section of water (A) temperature $\left({ }^{\circ} \mathrm{C}\right)$ and (B) salinity (psu) along a transect between stations $3 \mathrm{a}$ and $3 \mathrm{~d}$. The water column was almost homogeneous at stations $3 \mathrm{a}$ and $3 \mathrm{~b}$ but showed strong vertical stratification at stations $3 \mathrm{c}$ and $3 \mathrm{~d}$, with mixed layer depth of about $40 \mathrm{~m}$

Table 2

Pearson's correlation coefficient ( $r$ ) amongst physicochemical factors. Significant correlations $(p<0.05)$ are given in bold

\begin{tabular}{ccccc}
\hline Variables & Temperature & Salinity & $\mathrm{pH}$ & $\mathrm{DO}$ \\
\hline Temperature & & & & \\
Salinity & $\mathbf{- 0 . 4 0}$ & & & \\
pH & -0.22 & 0.12 & & \\
DO & -0.06 & -0.03 & $\mathbf{0 . 8 0}$ & \\
TChl & 0.47 & -0.38 & -0.77 & -0.71 \\
\hline
\end{tabular}

\section{Picophytoplankton Distribution and Abundance}

At all sampling stations, all picophytoplankton groups (i.e., Synechococcus, Prochlorococcus and picoeukaryotes) were identified according to their specific fluorescent properties and light scatter profiles. Overall, Synechococcus formed the dominant component of the 
picophytoplankton populations, covering about $72 \%$ of the surface waters in the study area. This was followed by Picoeukaryotes $(6 \%)$ while the remaining stations $(22 \%)$ corresponded to the mixed picophytoplankton population. Although present at most stations, Prochlorococcus was not the dominant contributors $(<35 \%)$ to the picophytoplankton community at any station.

Table 3 summarizes the data range of total picophytoplankton, and their respective groups and Figure 4 presents the spatial distribution of all picophytoplankton groups during the study period. As with TChl distribution, the population of total picophytoplankton displayed an obvious spatial distribution pattern $(\mathrm{CV}=41 \%)$, averaging about one order of magnitude higher in coastal waters than in more clear offshore waters. The surface abundance of total picophytoplankton was highly variable, ranging from 4.61 to $24.29 \times 10^{4}$ cells $\mathrm{ml}^{-1}$ (mean $14.61 \pm 6.01$ ), where the highest cell density was observed at station $5 \mathrm{a}$ and the lowest at station 1c. The most dominant picophytoplankton, Synechococcus, showed a high variability in density, with an average value of $7.36 \pm 3.29 \times 10^{4}$ cells $\mathrm{ml}^{-1}$, accounting for $50.3 \%$ of the total picophytoplankton abundance. The maximum Synechococcus abundance was primarily distributed along the coast and progressively decreased seaward, although relatively high densities (as high as $\sim 8.0 \times 10^{4}$ cells $\mathrm{ml}^{-1}$ ) were observed to have spread far offshore and moved northeast in the direction of the prevailing wind (Figure 4A). Along the coast, higher surface densities of Synechococcus were clearly apparent in the Pahang coastal waters, especially at stations $1 \mathrm{~b}$ and $2 \mathrm{a}$, than those observed in Johor waters. On the other hand, Prochlorococcus was poorly represented in density $(<19 \%$ of total picophytoplankton), with an average value of $2.59 \pm 1.42 \times 10^{4}$ cells ml-1. In contrast to Synechococcus and picoeukaryotes, the Prochlorococcus population (Figure 4B) showed a patchy surface distribution pattern that did not vary spatially from coastal to offshore waters. The highest density of Prochlorococcus was clearly observed at two intermediate stations (stations $1 \mathrm{~b}$ and $6 \mathrm{~b}$ ) while the lowest density was mostly dominated in the middle parts of the study area and at a few coastal stations (stations 2a, 3a, and 5a). It was also shown that there was a slightly increasing trend in Prochlorococcus abundances from the middle parts of the study area to the open oceanic waters. Picoeukaryotes was the second most abundant picophytoplankton group in the area, constituting an average of $30.8 \%$ of the total picophytoplankton. On average, $4.66 \pm 3.33 \times 10^{4}$ cells $\mathrm{ml}^{-1}$ of picoeukaryotes was measured in the study area. Similar to Synechococcus distribution, the picoeukaryotes assemblage (Figure 4C) was characterized by a strong decreasing density gradient, with maximum values concentrating along the coast and minimum values in the offshore waters. Contrary to what has been observed in Synechococcus, the maximum densities of picoeukaryotes were particularly confined to the southern coast of Johor, with the highest value observed at station $5 \mathrm{a}$. 
Table 3

Average density (mean \pm standard deviation), range, and coefficient of variation (CV, \%) values of total picophytoplankton, Synechococcus, Prochlorococcus and picoeukaryotes in surface water of southeastern coast of Peninsular Malaysia

\begin{tabular}{cccc}
\hline Picophytoplankton group & $\begin{array}{c}\text { Average } \\
\text { Density }\left(\mathrm{x} 10^{4} \text { cells ml }{ }^{-1}\right)\end{array}$ & Range & CV \\
\hline Synechococcus & $7.36 \pm 3.29$ & $2.13-13.65$ & $45 \%$ \\
Prochlorococcus & $2.59 \pm 1.42$ & $0.52-5.86$ & $55 \%$ \\
Picoeukaryotes & $4.66 \pm 3.33$ & $1.37-14.43$ & $71 \%$ \\
Total picophytoplankton & $14.61 \pm 6.01$ & $4.61-24.29$ & $41 \%$ \\
\hline
\end{tabular}
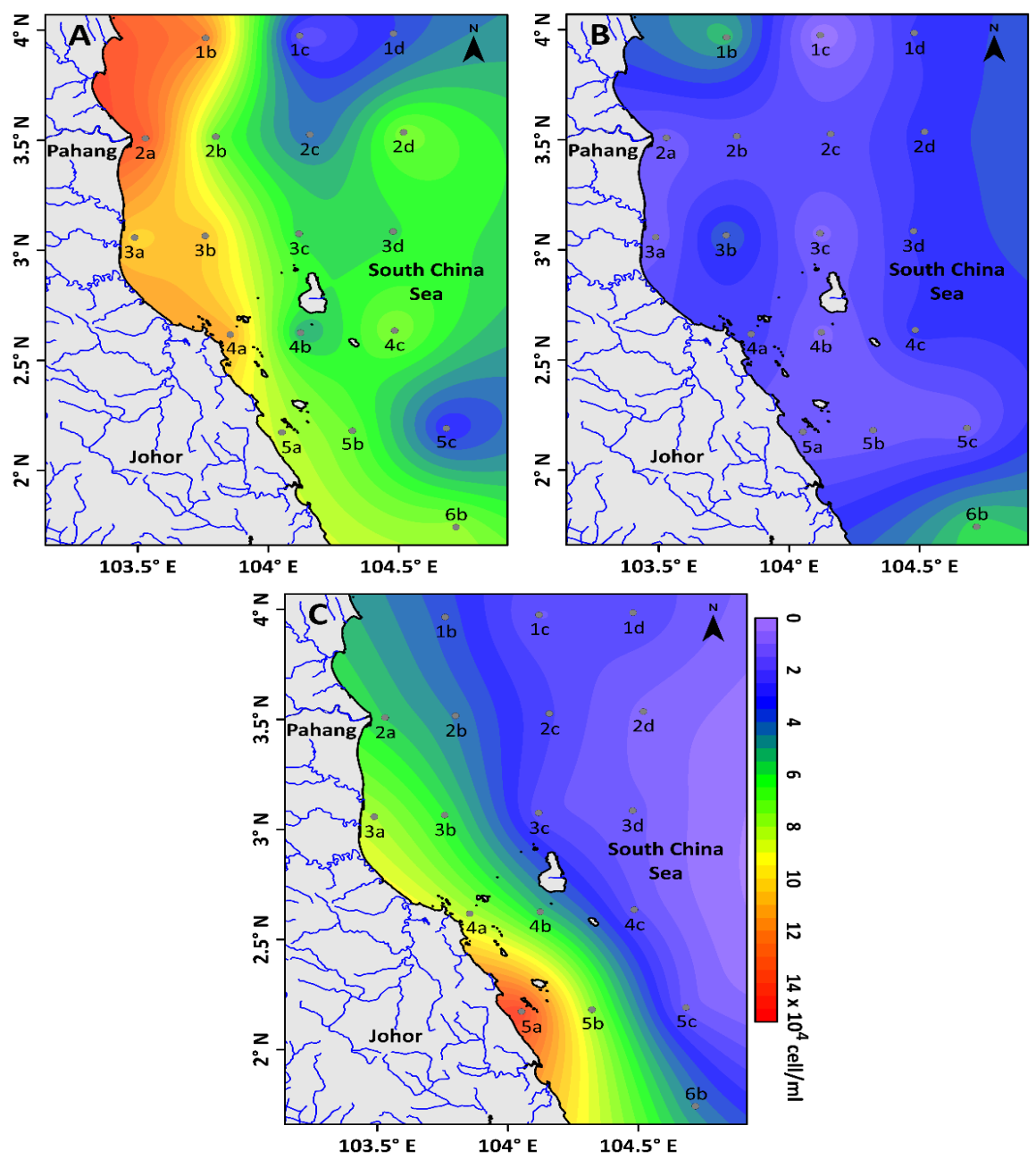

Figure 4. Spatial distributions of surface abundance (x $10^{4} \mathrm{cell} \mathrm{ml}^{-1}$ ) of A) Synechococcus, B) Prochlorococcus and $\mathrm{C}$ ) picoeukaryotes in the southeastern coast of Peninsular Malaysia 
Differences in the fraction contributed by each picophytoplankton group along the coastal-offshore gradients were also assessed with all data were pooled according to distance from the coastline. The percentage contribution to total picophytoplankton along coastaloffshore stations showed a clear difference between each picophytoplankton assemblage (Figure 5). The relative contribution of Synechococcus was slightly high with increasing distance offshore (from 50 to $52 \%$ ), indicating the strong ability of this assemblage to adapt to a range of environmental conditions. Meanwhile, the relative contribution of picoeukaryotes to total picophytoplankton showed a decreasing linear trend, from $\sim 40 \%$ at the coastal stations to $\sim 18 \%$ at the offshore stations, suggesting the decreasing importance of this assemblage among picophytoplankton groups with increasing distance offshore. In contrast, the minimum contribution of Prochlorococcus was found at the coastal stations $(<10 \%)$, rather than at the offshore stations $(\sim 30 \%)$.

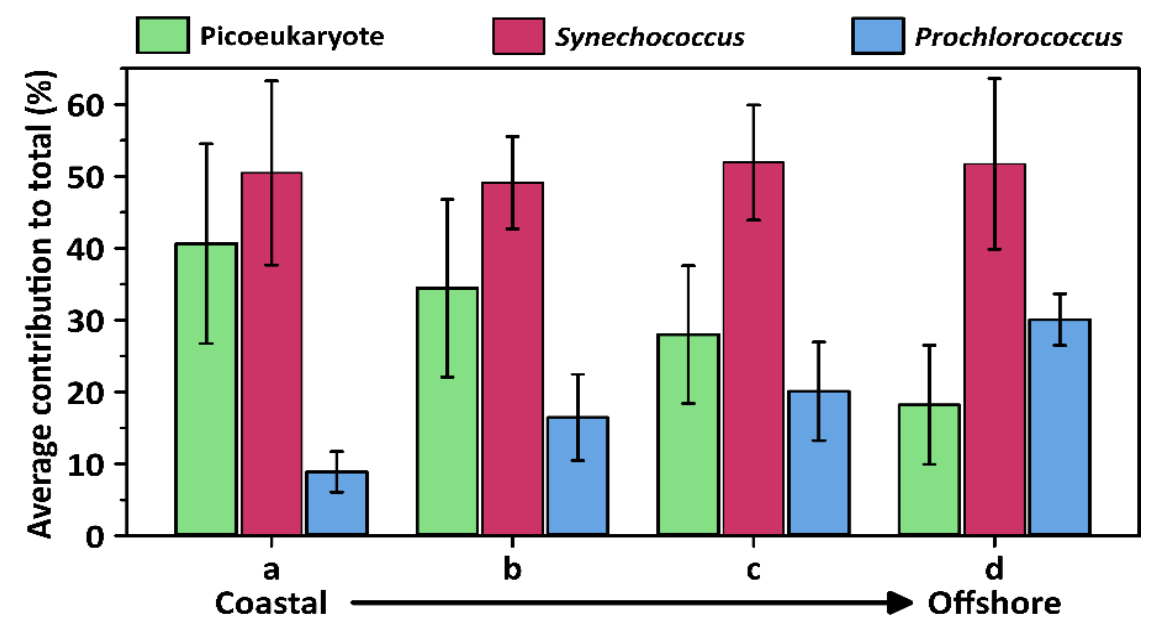

Figure 5. Relative contribution (\%) of picoeukaryotes, Synechococcus and Prochlorococcus assemblages to total picophytoplankton population from coastal (a) to offshore stations (d) in the southeastern coast of Peninsular Malaysia. Error bars represent one standard deviation of the mean

\section{Influence of Environmental Conditions on Picophytoplankton Populations}

The correlation between picophytoplankton groups and environmental conditions identified with Canonical Correlation Analysis (CCA) is depicted in Figure 6. The first two axes of CCA (F1 and F2) were significant ( $\mathrm{p}<0.03$ ) as evidenced by the Wilks' Lambda test, explaining $90 \%$ of the variability in the picophytoplankton and environmental conditions relationship (55.2\% and 34.9\% for axes 1 and 2, respectively). Moreover, there were strong correlations between picophytoplankton groups and environmental variables for the first axis $(r=0.92, p<0.03)$ and second axis $(r=0.73, p<0.03)$, indicating a strong influence of environmental factors on the distribution of picophytoplankton population in the study area. The first environmental canonical axis (F1) was most negatively 
correlated with TChl $(\mathrm{r}=0.93)$ and most positively correlated with $\mathrm{pH}(\mathrm{r}=0.88)$ and DO $(r=0.66)$, while the second environmental axis (F2) was most negatively associated with temperature $(r=0.87)$ and positively associated with DO $(r=0.63)$ (Figure 6). For the picophytoplankton canonical variable, the first axis (F1) was most negatively correlated with total picophytoplankton $(\mathrm{r}=0.85)$, Synechococcus $(\mathrm{r}=0.82)$ and picoeukaryotes $(\mathrm{r}$ $=0.78)$, while the second axis (F2) was most negatively associated with Prochlorococcus $(\mathrm{r}=0.89)$ and total picophytoplankton $(\mathrm{r}=0.53)$ (Figure 6).

Correlations between the abundances of picophytoplankton assemblages and environmental conditions for both canonical axes (F1 \& F2) (Figure 6 \& Table 4) suggested that different assemblages were influenced by different environmental conditions. For the first canonical axis, total picophytoplankton, Synechococcus and picoeukaryotes had a strong positive correlation with TChl $(\mathrm{r}=0.72,0.70,0.66)$, and negative correlation with $\mathrm{pH}(\mathrm{r}=-0.85,-0.76,-0.71)$ and DO $(\mathrm{r}=-0.76,-0.61,-0.64)$. This indicates that an increased in TChl and a decrease in $\mathrm{pH}$ and DO would favor the development of these assemblages. In the second canonical axis, Prochlorococcus was the only assemblage to exhibit a strong negative association with temperature $(\mathrm{r}=-0.66)$, which indicated that low temperature is the favorable condition for their growth. Similar to the first canonical axis, total picophytoplankton, Synechococcus and picoeukaryotes also had a negative correlation with DO, suggesting that this environmental parameter had a significant influence on the abundance and composition of picophytoplankton community.

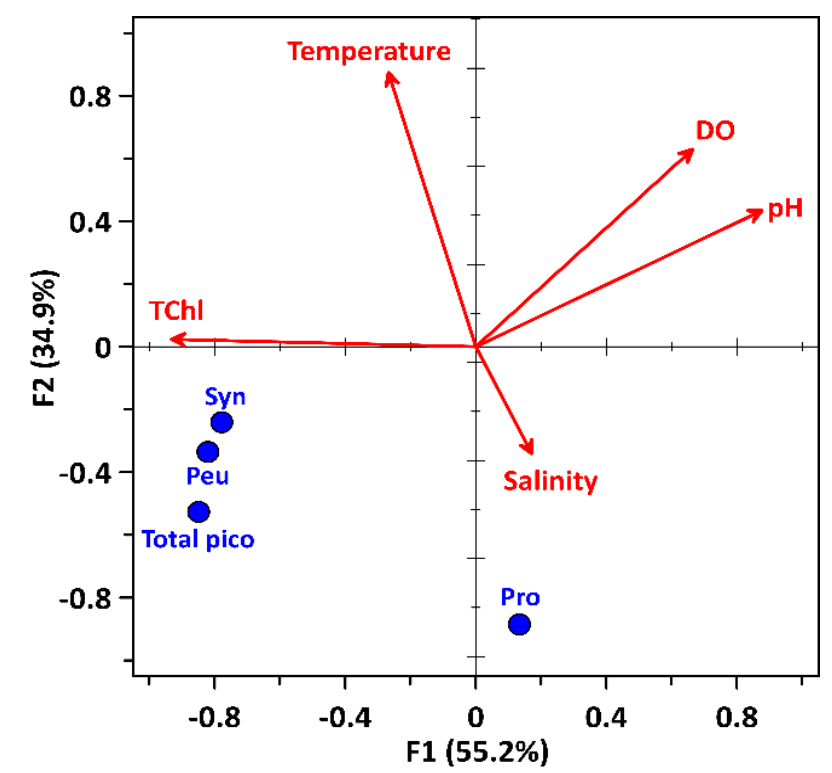

Figure 6. Canonical correlation analysis (CCA) ordination diagram of total (Total pico) and picophytoplankton groups (Syn: Synechococcus, Pro: Prochlorococcus and Peu: picoeukaryotes) with environmental variables (TChl, temperature, salinity, $\mathrm{pH}$ and DO) in the southeastern coast of Peninsular Malaysia. The percentage of the variation in the picophytoplankton groups for each axis (F1 and F2) is indicated in parentheses next to the axis label. 
Table 4

Pearson's correlation coefficient (r) between physicochemical factors and total picophytoplankton, Synechococcus, Prochlorococcus and picoeukaryotes populations. Significant correlations $(p<0.05)$ are given in bold.

\begin{tabular}{ccccc}
\hline Variables & $\begin{array}{c}\text { Total } \\
\text { picophytoplankton }\end{array}$ & Synechococcus & Prochlorococcus & Picoeukaryotes \\
\hline Temperature & -0.13 & -0.08 & $\mathbf{- 0 . 6 6}$ & 0.12 \\
Salinity & 0.00 & 0.02 & 0.31 & -0.15 \\
pH & $\mathbf{- 0 . 8 5}$ & $\mathbf{- 0 . 7 6}$ & -0.17 & $\mathbf{- 0 . 7 1}$ \\
DO & $\mathbf{- 0 . 7 6}$ & $\mathbf{- 0 . 6 1}$ & -0.29 & $\mathbf{- 0 . 6 4}$ \\
TChl & $\mathbf{0 . 7 2}$ & $\mathbf{0 . 7 0}$ & -0.13 & $\mathbf{0 . 6 6}$ \\
\hline
\end{tabular}

\section{DISCUSSION}

Environmental conditions in the study area are generally associated with the monsoonal systems which have a great influence on the physical, chemical, and biological processes of the water column (Liu et al., 2002; Liu \& Chai 2009; Powley et al., 2017; Wei et al., 2020). The results of this study clearly reveal the typical oligotrophic conditions with low concentrations of total Chlorophyll (TChl) dominated the surface water of the study area. Particularly during the southwest monsoon (SWM), strong vertical stratification due to sea surface heating and weak wind could result in nutrient limitation and low phytoplankton productivity (Zainol \& Akhir, 2016; Akhir et al., 2014; Yanagi et al., 2001). High TChl levels along the coast especially at station very close to river mouths (e.g., station 3a) could be attributed to significant freshwater discharge that cause nutrient enrichment in coastal waters (Powley et al., 2017; Wei et al., 2020).

The present study showed that picophytoplankton was represented by Synechococcus, followed by picoeukaryotes and Prochlorococcus. The observed trend towards an increase of TChl concentration, consistent with an increase in picophytoplankton abundance indicated that these groups of phytoplankton are the dominant contributors to TChl in the study area, except for Prochlorococcus. The ubiquity of Synechococcus spp. during our study confirms the ability of this genus to adapt to a local coastal-offshore variable environment. Synechococcus is known to be ubiquitous in most of the world's oceans (Gin et al., 2003; Li, 1998) and can dominate in subtropical regions with stronger 
temperature fluctuations. On the other hand, Prochlorococcus is commonly more abundant in oligotrophic waters (Campbell et al., 1994; Partensky et al., 1999a; Partensky et al., $1999 \mathrm{~b}$ ) and ubiquitous in the latitudinal band from $40^{\circ} \mathrm{N}$ to $40^{\circ} \mathrm{S}$ (Partensky et al., 1999b) while picoeukaryotes mainly dominated in coastal systems (Mouriño-Carballido et al., 2016). Although the maximum values for Synechococcus abundance found in this study are close to those reported in previous studies (Agusti et al., 2019; Chen et al., 2009), Prochlorococcus population abundance was found to be two-three orders of magnitude lower than the populations found in the global data set (Agusti et al., 2019; Flombaum et al., 2013). In accordance with our finding, studies reveal that Synechococcus accumulated higher than Prochlorococcus and picoeukaryotes in tropical and equatorial ocean from surface waters down to the base of thermocline (Partensky et al., 1999a; Mena et al., 2019; Pan et al., 2007). Contrastingly, some studies found Prochlorococcus to be more abundant than Synechococcus in the North Atlantic, South Pacific, North Indian basins (Buitenhuis et al., 2012), the subtropical and tropical ocean (Agusti et al., 2019; Chen et al., 2009), including south China Sea (Jiang \& Sun, 2020; Wei et al., 2020).

These differences could be due to variation in phytoplankton adaptation to several factors such as temperature, photosynthetic active radiation (PAR), light conditions and nutrient, which may have led to the segregation of their maximal distributions across space and through time (Flombaum et al., 2013; Mella-Flores et al., 2012). Laboratory analysis showed that the optimum temperature for Synechococcus and Prochlorococcus growth was $24^{\circ} \mathrm{C}$ and $28^{\circ} \mathrm{C}$, respectively (Moore et al., 1995). However, the results are most likely strain- or clone- specific as Prochlorococcus spp. has been detected at water temperatures of up to $30^{\circ} \mathrm{C}$, with maximum integrated concentrations was between 26 and $29^{\circ} \mathrm{C}$ in the warm equatorial and South Pacific waters, and the Red Sea at the surface (Moore et al., 1995; Partensky et al., 1999b). A previous study in the upper $200 \mathrm{~m}$ of the subtropical regions of the Pacific, Atlantic and Indian oceans using a compilation of flowcytometry data indicates that the Prochlorococcus distributions were controlled by temperature and PAR(400-700 nm, Flombaum et al., 2013). However, this prediction of increasing abundance with increasing temperature in the subtropical and tropical ocean (Flombaum et al., 2013), is inconsistent with our results for the southeastern coast of Peninsular Malaysia. Our findings showed no clear effect of temperature on Synechococcus and picoeukaryotes, but Prochlorococcus abundance decreased with increasing temperature suggesting that high temperature negatively affects the Prochlorococcus concentration in the study area. This difference could be the result of different ecotype with different temperature optima or thermal sensitivity (Otero-Ferrer et al., 2018). The global model considering interactions between environmental variables predicted a population decline at the surface water with warming (Agusti et al., 2019), indicating that increased surface stratification, higher underwater PAR and Ultraviolet (UVB) penetration should inhibit 
the surface populations of picophytoplankton in the water column. According to Agusti et al. (2019) and Wei et al. (2020), Prochlorococcus are more sensitive to light intensity and better adapted to absorb blue wavelengths that predominate deeper in the water column. Unfortunately, the abundance of Prochlorococcus ecotypes has not been assessed during this study to validate this.

Alternatively, according to Otero-Ferrer et al. (2018), nutrient supply was the main factor that determined the distribution of the picophytoplankton community in highly contrasting marine environments in the Atlantic Ocean. High abundances of Synechococcus and picoeukaryotes have been reported under nutrient-rich conditions typical of coastal surface waters affected by mixing or upwellings (Echevarría et al., 2009; Sherr et al., 2005). Previous research suggests that picophytoplankton commonly dominate in waters with concentrations of nutrient $<1 \mu \mathrm{M}$. At higher concentrations, the contribution of picophytoplankton to total biomass and production decreased significantly (Agawin et al., 2000b). According to Liu et al. (1997) and Agawin (2000a), the optimal nutrient concentration for Synechococcus growth was $0.25 \mu \mathrm{M}$ nitrogen $(\mathrm{N})$ in the Mediterranean Sea and $0.1-3 \mu \mathrm{M} N$ in the Arabian Sea. High concentrations of about $>8 \mu \mathrm{M}$ could inhibit Synechococcus growth. However, no data on nutrient concentration was recorded during this study period. A previous study has shown that surface nitrate was observed in a range between $1.6 \mu \mathrm{M}$ (offshore) and $6.4 \mu \mathrm{M}$ (coastal) in the Pahang coast (Shaari et al., 2013). Our results showed that Synechococcus are the most successful group among the picophytoplankton in Pahang coastal waters (Station 1a, 2b, Figure 4) where we would expect an influence of the nutrient derived from the riverine and the aquaculture area output to this area, as indicated in Shaari et al. (2013). Nevertheless, several studies could not find a clear relationship between nutrient concentration and cell abundance of picophytoplankton (Flombaum et al., 2013; Guo et al., 2014; Mouriño-Carballido et al., 2016; Wei et al., 2020).

Overall, both physical and biological parameters were likely to have an effect on DO values. Similarly, previous studies conducted in Ireland Estuary and Bengal Bay noticed a positive tight coupling between pH and DO (O'Boyle et al., 2013; Shaik et al., 2017). The significant correlation between $\mathrm{pH}$ and phytoplankton (both TChla concentrations and picophytoplankton density) indicated that biological activities had a substantial effect on $\mathrm{pH}$ (Shi et al., 2019). In general, when any aquatic environment is governed by autotrophy, $\mathrm{CO}_{2}$ is eliminated by photosynthesis, resulting in a rise in $\mathrm{pH}$ values. In comparison, when heterotrophy is dominant, microbial respiration releases more $\mathrm{CO}_{2}$ than photosynthetic carbon uptake, thus reduces $\mathrm{pH}$ level (Shaik et al., 2017). However, further research is needed to justify this in the study area.

Moreover, several studies have reported that the transition of the picophytoplankton population may also depend on other factors which were not the scope of this study such 
as sedimentation (Brussaard et al., 1995), turbulence (Huisman et al., 2004), the balance between growth and grazing and viral lysis (Weinbauer \& Höfle, 1998). In term of grazing pressure, zooplankton filter feeders and heterotrophic flagellates are thought to maintain the biomass of its prey and thus changes in picophytoplankton growth rate may significantly alter the resulting biomass of the picophytoplankton subgroups (Calbet et al., 2008; Chen et al., 2009). However, studies have shown that Synechococcus tend to be a poor food source for nanoflagellates (Dolan \& Šimek, 1999). But in terms of viral lysis, it was reported Synechococcus cells could lose 5 to $77 \%$ daily in the open ocean (Evans \& Brussaard, 2012; Suttle \& Chan, 1994; Wang et al., 2011). Thus, we believe that such alternative explanations do not preclude each other, because the ecological pattern of distribution of plankton biomass in a particular area is more likely to be influenced by a combination of some (or many) factors.

\section{CONCLUSION}

Our results for the first-time covering the surface distribution of picophytoplankton in the southeastern coast of Peninsular Malaysia. This study revealed a coastal-offshore gradient dominated by Synechococcus, followed by picoeukaryotes and Prochlorococcus. Synechococcus and picoeukaryote abundance was primarily distributed along the coast and progressively decreased seaward, whereas Prochlorococcus abundances showed a slight increasing trend from the middle parts of the study area to the open oceanic waters. Our observation of physicochemical factors has enabled us to obtain a better understanding of the factors controlling the picophytoplankton composition. The results of canonical correspondence analysis demonstrate that TChl, $\mathrm{pH}, \mathrm{DO}$ and temperature would favor the abundance of picophytoplankton assemblages in the study areas. However, the inclusion of accurate nutrient level and functional characteristics - such as size, pigments, biomass and photosynthetic properties - in future phytoplankton studies may be suggested in order to better understand the distribution of picophytoplankton at high spatial and/or temporal resolution, which could lead to a detailed understanding of abundance data from a broader ecological perspective.

\section{ACKNOWLEDGEMENTS}

This work was supported by the Ministry of Higher Education Malaysia, under the Fundamental Research Grant Scheme (FRGS) (Vote No. 59246) and Higher Institution Centre of Excellence (HICoE) Research Grant (Vote No. 66928) Institute of Oceanography and Environment (INOS), Universiti Malaysia Terengganu. Sincere thanks to Ms See Hui Shien from the Biomarketing service for the flow cytometry analysis and RV Discovery's crews for great support onboard. 


\section{REFERENCES}

Agawin, N. S. R., Duarte, C. M., \& Agusti, S. (2000a). Response of Mediterranean Synechococcus growth and loss rates to experimental nutrient inputs. Marine Ecology Progress Series, 206, 97-106. https://doi. org/10.3354/meps206097

Agawin, N. S. R., Duarte, C. M., \& Agustí, S. (2000b). Nutrient and temperature control of the contribution of picoplankton to phytoplankton biomass and production. Limnology and Oceanography, 45(3), 591-600. https://doi.org/10.4319/1o.2000.45.3.0591

Agawin, N. S. R., Duarte, C. M., Agustí, S., \& McManus, L. (2003). Abundance, biomass and growth rates of Synechococcus sp. in a tropical coastal ecosystem (Philippines, South China Sea). Estuarine, Coastal and Shelf Science, 56, 49-502. https://doi.org/10.1016/S0272-7714(02)00200-7

Agusti, S., Lubián, L. M., Moreno-Ostos, E., Estrada, M., \& Duarte, C. M. (2019). Projected changes in photosynthetic picoplankton in a warmer subtropical ocean. Frontiers in Marine Science, 5, Article 506. https://doi.org/10.3389/fmars.2018.00506

Akhir, M., Zakaria, N., \& Tangang, F. (2014). Intermonsoon variation of physical characteristics and current circulation along the east coast of Peninsular Malaysia. International Journal of Oceans and Oceanography, 2014, Article 527587. https://doi.org/10.1155/2014/527587.

Biller, S. J., Berube, P. M., Lindell, D., \& Chisholm, S. W. (2015). Prochlorococcus: The structure and function of collective diversity. Nature Reviews Microbiology, 13(1), 13-27. https://doi.org/10.1038/nrmicro3378

Brussaard, C. P., Riegman, R., Noordeloos, A. A., Cadee, G. C., Witte, H., Kop, A. J., Nieuwland, G., Van Duyl, F. C., \& Bak, R. P. (1995). Effects of grazing, sedimentation and phytoplankton cell lysis on the structure of a coastal pelagic food web. Marine Ecology Progress Series, 123(1), 259-271. https://doi. org/10.3354/meps 123259

Buitenhuis, E. T., Li, W. K. W., Vaulot, D., Lomas, M. W., Landry, M. R., Partensky, F., Karl, D. M., Ulloa, O., Campbell, L., Jacquet, S., Lantoine, F., Chavez, F., MacIas, D., Gosselin, M., \& McManus, G. B. (2012). Picophytoplankton biomass distribution in the global ocean. Earth System Science Data, 4, 37-46. https://doi.org/10.5194/essd-4-37-2012

Calbet, A., Trepat, I., Almeda, R., Saló, V., Saiz, E., Movilla, J. I., Alcaraz, M., Yebra, L., \& Simó, R. (2008). Impact of micro- And nanograzers on phytoplankton assessed by standard and size-fractionated dilution grazing experiments. Aquatic Microbial Ecology, 50, 145-156. https://doi.org/10.3354/ame01171

Campbell, L., Nolla, H. A., \& Vaulot, D. (1994). The importance of Prochlorococcus to community structure in the central North Pacific Ocean. Limnology and Oceanography, 39(4), 954-961. https://doi.org/10.4319/ 10.1994.39.4.0954.

Chen, B., Liu, H., Landry, M. R., Dai, M., Huang, B., \& Sun, J. (2009). Close coupling between phytoplankton growth and microzooplankton grazing in the western South China Sea. Limnology and Oceanography, 54(4), 1084-1097. https://doi.org/10.4319/1o.2009.54.4.1084

Chisholm, S. W., Olson, R. J., Zettler, E. R., Goericke, R., Waterbury, J. B., \& Welschmeyer, N. A. (1988). A novel free-living prochlorophyte abundant in the oceanic euphotic zone. Nature, 334, 340-343. https:// doi.org/10.1038/334340a0 
Dolan, J. R., \& Šimek, K. (1999). Diel periodicity in Synechococcus populations and grazing by heterotrophic nanoflagellates: Analysis of food vacuole contents. Limnology and Oceanography, 44, 1565-1570. https:// doi.org/10.4319/1o.1999.44.6.1565

Echevarría, F., Zabala, L., Corzo, A., Navarro, G., Prieto, L., \& Macías, D. (2009). Spatial distribution of autotrophic picoplankton in relation to physical forcings: The Gulf of Cádiz, Strait of Gibraltar and Alborán Sea case study. Journal of Plankton Research, 10(24), 9824-9829. https://doi.org/10.1093/plankt/fbp070

Evans, C., \& Brussaard, C. P. D. (2012). Viral lysis and microzooplankton grazing of phytoplankton throughout the Southern Ocean. Limnology and Oceanography, 54, 1826-1837. https://doi.org/10.4319/ 10.2012.57.6.1826

Flombaum, P., Gallegos, J. L., Gordillo, R. A., Rincón, J., Zabala, L. L., Jiao, N., Karl, D. M., Li, W. K. W., Lomas, M. W., Veneziano, D., Vera, C. S., Vrugt, J. A., \& Martiny, A. C. (2013). Present and future global distributions of the marine Cyanobacteria Prochlorococcus and Synechococcus. Proceedings of the National Academy of Sciences of the United States of America, 110(24), 9824-9829. https://doi. org/10.1073/pnas. 1307701110

Gasol, J. M., Del Giorgio, P. A., \& Duarte, C. M. (1997). Biomass distribution in marine planktonic communities. Limnology and Oceanography, 42(6), 1353-1363. https://doi.org/10.4319/1o.1997.42.6.1353

Gin, K. Y. H., Lin, X., \& Zhang, S. (2000). Dynamics and size structure of phytoplankton in the coastal waters of Singapore. Journal of Plankton Research, 22(8), 1465-1484. https://doi.org/10.1093/plankt/22.8.1465

Gin, K. Y. H., Zhang, S., \& Lee, Y. K. (2003). Phytoplankton community structure in Singapore's coastal waters using HPLC pigment analysis and flow cytometry. Journal of Plankton Research, 25(12), 1507-1519. https://doi.org/10.1093/plankt/fbg112

Guiry, M. D., \& Guiry, G. M. (2016). AlgaeBase. World-wide electronic publication. National University of Ireland. Retrieved November 15, 2020, from https://doi.org/http://www.algaebase.org/search/genus/ detail/?genus_id=43474

Guo, C., Liu, H., Zheng, L., Song, S., Chen, B., \& Huang, B. (2014). Seasonal and spatial patterns of picophytoplankton growth, grazing and distribution in the East China Sea. Biogeosciences, 11(7), 18471862. https://doi.org/10.5194/bg-11-1847-2014

Huisman, J., Sharples, J., Stroom, J. M., Visser, P. M., Kardinaal, W. E. A., Verspagen, J. M. H., \& Sommeijer, B. (2004). Changes in turbulent mixing shift competition for light between phytoplankton species. Ecology, 85(11), 2960-2970. https://doi.org/10.1890/03-0763

Jiang, Z. Y., \& Sun, F. L. (2020). Diversity and biogeography of picoplankton communities from the Straits of Malacca to the South China Sea. Oceanological and Hydrobiological Studies, 49(1), 23-33. https:// doi.org/10.1515/ohs-2020-0003

Jeffrey, S. W., \& Humphrey, G. F. (1975). New spectrophotometric equations for determining chlorophylls a, b, c1 and c2 in higher plants, algae and natural phytoplankton. Biochemie Und Physiologie Der Pflanzen, 167, 191-194. https://doi.org/10.1016/s0015-3796(17)30778-3

Lee, C. W., Bong, C. W., Ng, C. C., \& Alias, S. A. (2006). Factors affecting variability of heterotrophic and phototrophic microorganisms at high water in a mangrove forest at Cape Rachado, Malaysia. Malaysian Journal of Science, 25(2), 55-66. 
Lee, C. W., Lim, J. H., \& Heng, P. L. (2013). Investigating the spatial distribution of phototrophic picoplankton in a tropical estuary. Environmental Monitoring and Assessment, 185, 9697-9704. https://doi.org/10.1007/ s10661-013-3283-3

Li, W. K. W. (1998). Annual average abundance of heterotrophic bacteria and Synechococcus in surface ocean waters. Limnology and Oceanography, 43(7), 1746-1753. https://doi.org/10.4319/lo.1998.43.7.1746.

Liu, G., \& Chai, F. (2009). Seasonal and interannual variability of primary and export production in the South China Sea: A three-dimensional physical-biogeochemical model study. ICES Journal of Marine Science, $66(2), 420-431$.

Liu, H., Jing, H., Wong, T. H. C., \& Chen, B. (2014). Co-occurrence of phycocyanin- and phycoerythrin-rich Synechococcus in subtropical estuarine and coastal waters of Hong Kong. Environmental Microbiology Reports, 6(1), 90-99. https://doi.org/10.1111/1758-2229.12111

Liu, H., Nolla, H. A., \& Campbell, L. (1997). Prochlorococcus growth rate and contribution to primary production in the equatorial and subtropical North Pacific Ocean. Aquatic Microbial Ecology, 12, 39-47. https://doi.org/10.3354/ame012039.

Liu, K. K., Chao, S. Y., Shaw, P. T., Gong, G. C., Chen, C. C., \& Tang, T. Y. (2002). Monsoon-forced chlorophyll distribution and primary production in the South China Sea: Observations and a numerical study. DeepSea Research Part I: Oceanographic Research Paper, 49(8), 1387-1412.

Lønborg, C., \& Søndergaard, M. (2009). Microbial availability and degradation of dissolved organic carbon and nitrogen in two coastal areas. Estuarine, Coastal and Shelf Science, 81(4), 513-520. https://doi. org/10.1016/j.ecss.2008.12.009

Marie, D., Simon, N., \& Vaulot, D. (2005). Phytoplankton cell counting by flow cytometry. Algal Culturing Techniques, 1, 253-267. https://doi.org/10.1016/b978-012088426-1/50018-4

Mella-Flores, D., Six, C., Ratin, M., Partensky, F., Boutte, C., Le Corguillé, G., Marie, D., Blot, N., Gourvil, P., Kolowrat, C., \& Garczarek, L. (2012). Prochlorococcus and Synechococcus have evolved different adaptive mechanisms to cope with light and uv stress. Frontiers in Microbiology, 3, Article 285. https:// doi.org/10.3389/fmicb.2012.00285

Mena, C., Reglero, P., Hidalgo, M., Sintes, E., Santiago, R., Martín, M., Moyà, G., \& Balbín, R. (2019). Phytoplankton community structure is driven by stratification in the oligotrophic Mediterranean Sea. Frontiers in Microbiology, 10, Article 1698. https://doi.org/10.3389/fmicb.2019.01698

Miyashita, H. (2015). Diversity of marine phototorophs. In S. K. Kim (Ed.), Springer handbook of marine biotechnology (pp. 27-34). Springer. https://doi.org/10.1007/978-3-642-53971-8

Moore, L. R., Goericke, R., \& Chisholm, S. W. (1995). Comparative physiology of Synechococcus and Prochlorococcus: Influence of light and temperature on growth, pigments, fluorescence and absorptive properties. Marine Ecology Progress Series, 116(1), 259-275. https://doi.org/10.3354/meps116259

Mouriño-Carballido, B., Hojas, E., Cermeño, P., Chouciño, P., Fernández-Castro, B., Latasa, M., Marañón, E., Morán, X. A. G., \& Vidal, M. (2016). Nutrient supply controls picoplankton community structure during three contrasting seasons in the northwestern Mediterranean Sea. Marine Ecology Progress Series, 543, 1-19. https://doi.org/10.3354/meps 11558 
Otero-Ferrer, J. L., Cermeño, P., Fernández-Castro, B., Gasol, J. M., Morán, X. A. G., Marañon, E., MoreiraCoello, V., Varela, M., Villamaña, M., \& Mouriño-Carballido, B. (2018). Factors controlling the community structure of picoplankton in contrasting marine environments. Biogeosciences Discussions, 15, 6199-6220. https://doi.org/10.5194/bg-2018-211

O’Boyle, S., McDermott, G., Noklegaard, T., \& Wilkes, R. (2013). A simple index of trophic status in estuaries and coastal bays based on measurements of $\mathrm{pH}$ and dissolved oxygen. Estuaries and Coasts, 36(1), 158173. https://doi.org/10.1007/s12237-012-9553-4

Pan, L. A., Zhang, J., \& Zhang, L. H. (2007). Picophytoplankton, nanophytoplankton, heterotrohpic bacteria and viruses in the Changjiang Estuary and adjacent coastal waters. Journal of Plankton Research, 29, 187-197. https://doi.org/10.1093/plankt/fbm006

Partensky, F., Blanchot, J., \& Vaulot, D. (1999a). Differential distribuition and ecology of Prochloococcus and Synechococcus in oceanic waters: A review. Bulletin de l'Institut oceanographique, Monaco, 19, 457-475.

Partensky, F., Hess, W. R., \& Vaulot, D. (1999b). Prochlorococcus, a Marine photosynthetic prokaryote of global significance. Microbiology and Molecular Biology Reviews, 63(1), 106-127. https://doi.org/10.1128/ mmbr.63.1.106-127.1999

Powley, H. R., Krom, M. D., \& Van Cappellen, P. (2017). Understanding the unique biogeochemistry of the Mediterranean Sea: Insights from a coupled phosphorus and nitrogen model. Global Biogeochemical Cycles, 31, 1010-1031. https://doi.org/10.1002/2017GB005648

Scanlan, D. J. (2012). Marine picocyanobacteria. In B. A. Whitton (Ed.), Ecology of Cyanobacteria II (pp. 503-533). Springer. https://doi.org/10.1007/978-94-007-3855-3_20

Shaari, F., Mustapha, M. A., Ali, M. M., \& Lihan, T. (2013, November). Chlorophyll-a and nutrient distribution of Pahang coastal waters during southwest monsoon using satellite images. In AIP Conference Proceedings (Vol. 1571, No. 1, pp. 493-497). American Institute of Physics. https://doi.org/10.1063/1.4858703

Sherr, E. B., Sherr, B. F., \& Wheeler, P. A. (2005). Distribution of coccoid cyanobacteria and small eukaryotic phytoplankton in the upwelling ecosystem off the Oregon coast during 2001 and 2002. Deep-Sea Research Part II: Topical Studies in Oceanography, 52, 317-330. https://doi.org/10.1016/j.dsr2.2004.09.020

Shaik, A. U. R., Biswas, H., \& Pal, S. (2017). Increased $\mathrm{CO}_{2}$ availability promotes growth of a tropical coastal diatom assemblage (Goa coast, Arabian Sea, India). Diatom Research, 32(3), 325-339. https://doi.org/1 0.1080/0269249X.2017.1379443

Shi, X., Li, S., Li, H., Chen, F., \& Wu, Q. (2019). The community structure of picophytoplankton in Lake Fuxian, a deep and oligotrophic mountain lake. Frontiers in Microbiology, 10, Article 2016. https://doi. org/10.3389/fmicb.2019.02016

Suttle, C. A., \& Chan, A. M. (1994). Dynamics and distribution of cyanophages and their effect on marine Synechococcus spp. Applied and Environmental Microbiology, 60(9), 3167-3174. https://doi.org/10.1128/ aem.60.9.3167-3174.1994

Vaulot, D., Eikrem, W., Viprey, M., \& Moreau, H. (2008). The diversity of small eukaryotic phytoplankton (< or $=3$ microm) in marine ecosystems. FEMS Microbiology Reviews, 32(5), 795-820. https://doi. org/10.1111/j.1574-6976.2008.00121.x 
Vaulot, D., Courties, C., \& Partensky, F. (1989). A simple method to preserve oceanic phytoplankton for flow cytometric analyses through division by the corresponding parameters. Cytometry, 10, 629-635.

Wang, K., Wommack, K. E., \& Chen, F. (2011). Abundance and distribution of Synechococcus spp. and cyanophages in the Chesapeake Bay. Applied and Environmental Microbiology, 77(21), 7459-7468. https://doi.org/10.1128/AEM.00267-11

Wei, Y., Huang, D., Zhang, G., Zhao, Y., \& Sun, J. (2020). Biogeographic variations of picophytoplankton in three contrasting seas: The Bay of Bengal, South China Sea and western Pacific Ocean. Aquatic Microbial Ecology, 84, 91-103. https://doi.org/10.3354/ame01928

Weinbauer, M. G., \& Höfle, M. G. (1998). Significance of viral lysis and flagellate grazing as factors controlling bacterioplankton production in a eutrophic lake. Applied and Environmental Microbiology, 64, 431-438. https://doi.org/10.1128/aem.64.2.431-438.1998.

Yanagi, T., Sachoemar, S. I., Takao, T., \& Fujiwara, S. (2001). Seasonal variation of stratification in the gulf of Thailand. International Journal of Oceans and Oceanography, 57, 461-470. https://doi. org/10.1023/A:1021237721368.

Yang, Y., \& Jiao, N. (2004). Dynamics of picoplankton in the Nansha Islands area of the South China Sea. Acta Oceanologica Sinica, 23, 493-504.

Zainol, Z., \& Akhir, M. F. (2016). Coastal upwelling in the vicinity of Tioman Island. Journal of Sustainability Science and Management Special Issue Number 1: The International Seminar on the Straits of Malacca and the South China Sea, 71-80.

Zhao, S., Wei, J., Yue, H., \& Xiao, T. (2010). Picophytoplankton abundance and community structure in the Philippine Sea, western Pacific. Chinese Journal of Oceanology and Limnology, 28(1), 88-95. https:// doi.org/10.1007/s00343-010-9274-0

Zwirglmaier, K., Jardillier, L., Ostrowski, M., Mazard, S., Garczarek, L., Vaulot, D., Not, F., Massana, R., Ulloa, O., \& Scanlan, D. J. (2008). Global phylogeography of marine Synechococcus and Prochlorococcus reveals a distinct partitioning of lineages among oceanic biomes. Environmental Microbiology, 10(1), 147-161. https://doi.org/10.1111/j.1462-2920.2007.01440.x 
